\title{
Is there a Conflict between Principles-based Standard Setting and Structured Electronic Reporting with XBRL?
}

\author{
Dirk Beerbaum - Maciej Piechocki - Christoph Weber
}

\begin{abstract}
:
National standard setters and external accounting observers continue to express concerns over a principles-based developed IFRS taxonomy. Considering the anticipated but unexpected SEC decision on March $3^{\text {rd }} 2017$ to adopt the IFRS taxonomy for electronic filings for Foreign Private Issuers by 2018 and the announcement of ESMA on December $22^{\text {nd }} 2016$ to base electronic filings in Europe on the IFRS taxonomy by 2020 signal that national regulators, external accounting observers and international regulators have a dissent. This paper reflects the expressed concerns by national standard setters. Applying a scientific approach, a comprehensive literature review is performed. The research question is if the rules-based IFRS taxonomy implies a conceptual conflict with the principlesbased IFRS. This paper concludes considering the academic literature although there is conceptual conflict between a principles-based accounting standard and the template-based taxonomy, from a normative perspective the IFRS taxonomy improves comparability and transparency supporting true and fair view. Our study also contributes to the principles-based vs. rule-based debate in the academic literature. The new aspect is the role of IT with structured electronic reporting, which requires detailed and specific requirements, for which rule-based accounting has advantages over principles-based accounting.
\end{abstract}

Key words: IFRS taxonomy; Principles-based; XBRL.

JEL classification: M42.

\section{Introduction}

According to comments released recently by national standard setters on the proposed enhanced due process for the development and the maintenance of the IFRS Taxonomy, principles-based accounting and the IFRS taxonomy are perceived as a conceptual conflict (IASB, 2016). "Whilst we acknowledge that standard setting and taxonomy development can and should inform each other, we are concerned that mandatorily bearing taxonomy constraints and limitations in

\footnotetext{
Dirk Beerbaum; Executive in Residence, Aalto University School of Business, Helsinki, Finland, <beerbaumdirk@gmail.com>.

Maciej Piechocki; BearingPoint, Speicherstraße 1, 60327 Frankfurt am Main, Germany, <maciej.piechocki@bearingpoint.com>.

Christoph Weber; Landesbank Hessen-Thüringen, Neue Mainzer Straße 52-58, 60311 Frankfurt am Main, Germany, <christoph.weber@ helaba.de>.

We are grateful for comments received by the accounting research seminar of Aalto University

School of Business and Prof. Dr. Werner, Frankfurt School of Finance \& Management.
} 
Beerbaum, D. - Piechocki, M. - Weber, C.: Is there a Conflict between Principles-based Standard Setting and Structured Electronic Reporting with XBRL?

mind when developing standards bears the risk of the standards themselves becoming more rules- and less principles-based. We certainly agree that the pronouncements must be articulated clearly enough to enable appropriate representation through the taxonomy; however, a taxonomy's requirements should not be the key driver for developing standards and interpretations" (Accounting Standards Committee of Germany (ASCG)). National standard setter see the risks that through the change of the planned due process for the development of the IFRS taxonomy, IFRS might become more rules-based. Currently, the process of standard setting is not aligned to the development of the IFRS taxonomy. The IFRS taxonomy is derived from the standard and the taxonomy developers are not able to influence the standard setting process. With the planned integration of the taxonomy development into the standard setting process national standard setter such the Swedish Financial Reporting Board express their concerns: "We fear that bringing XBRL into standard setting will be detrimental to the principles based approach, particularly as regards the presentation of disclosures."

According to the Korean Accounting Standards: "It should be more conspicuously clarified that the IFRS Taxonomy is not guidance for IFRS in order not to deteriorate the principles-based standard setting approach." (IASB, 2016). Another commentator from a Big-4 audit firm said: "There is a risk that the design and content of a taxonomy that is intended to be used to capture information in general purpose financial reports will, or be perceived to, influence how those reports are prepared. Filing requirements that used prescribed data structures could undermine principles-based reporting requirements" (IASB, 2016).

The IASB has always pointed out to the non-prescriptive character of the IFRS taxonomy and several times precisely declared that the taxonomy is only derived from the standards and is not intended to substitute its domain (Debreceny et al., 2009). A technology like XBRL is an open-architecture technology and it is neither rule nor principles-based as it is extensible and can be used for several GAAPs offering high flexibility incorporating algorithmic solutions. This can be traced back to early works from Cohen (2004) about XBRL, who stresses the customization capability of XBRL. This can also be transferred to the taxonomy, which contains extensible flexible elements, as per designed functionality. XBRL is like meeting "old accounting economy" with paper based non-structured reporting and "new accounting economy" with real-time automatic postings. Moreover, a conceptual conflict would imply contrasting reasoning between rules and principles. To avoid such a conflict requires that the rules are consistently derived from the principles. A practical example that such a conflict can arise even within the IFRS standard setting process is the further development of the Conceptual Framework, which also need to ensure to be in line with existing rules and the existing framework. According to Verheij the logical structure of rules and principles are even the same (Verheij et al., 1998). If a condition of rule is met as a 
consequence the rule is directly applied. A principle gives rise to a reason for its conclusion if it applies.

On several occasions, EFRAG has expressed the view that the development of the IFRS taxonomy should not drive the IASB standard setting process, because it risks moving away from a principles-based approach, in particular in the area of disclosures. "However, we reiterate our comments made with references to the Request for Views Trustees' Review of structure and Effectiveness: Issues for the Review that the Taxonomy should not be integrated in the IASB standard setting process because we see the risk that this may take the IASB away from a principles-based approach when it develops accounting standards, in particular in the area of disclosures." An argument, which is very often provided is that the IASB should be involved with the development and maintenance of the IFRS Taxonomy. If the IASB is not, others will develop taxonomies and will try to fill those gaps. The FinRep taxonomy developed by the European Banking Authority (EBA) is a taxonomy developed for financial industry, although the IFRS are clearly non industry-specific, EBA makes references to IFRS within its taxonomy. Another often cited academic article on the IFRS taxonomy reveals that companies from the banking and insurance sector are confronted with the conflict that the degree of misfit between the IFRS taxonomy and the reported financial information is greater due to very specific characteristics compared to industrial and commercial companies (Bonsón et al., 2009).

Historically, this discussion can be traced back to the long standing principlesbased vs. rule-based debate in the academic literature (Benston et al., 2006b; Bradbury and Schröder, 2012; Wüstemann and Wüstemann, 2010). The principles-based vs. rule-based debate in the U.S. was rediscussed after the Enron and WorldCom accounting scandal 2002 (Nobes, 2005). An intense discussion whether US GAAP should become more principles-based, as rules-based standards might give rise to "cook-book accounting", without considering a substance-over-form approach (Parfet, 2000). So if there is no discretion to the chef, the taste will always be the same. US GAAP tends to be mechanical and inflexible. Clear-cut rules have some advantages, but the risk is that this approach motivates financial engineering designed specifically to circumvent these knifeedge rules, as is very often given proof in the tax literature (Healy and Palepu, 2003). According to Nelson (2003) a standard should not be seen as only principles or rule-based but should rather be regarded as more or less rule-based. According to a behavioral analysis Nelson concludes that rules can improve the accuracy of the communication of the standard setter and reduce imprecision associated with aggressive reporting due to unawareness of existing rules (Nelson, 2003). Nelson does not consider that rules increase imprecision but also enable companies to structure transactions to meet the accounting rule without following the true economic substance of the transaction. This is one of the main arguments 
Beerbaum, D. - Piechocki, M. - Weber, C.: Is there a Conflict between Principles-based Standard Setting and Structured Electronic Reporting with XBRL?

by supporter of principles or concepts-based accounting (Maines et al., 2003). Maines et al. point to the challenge when moving from a rule-based to a conceptsbased standard setting, as informed professional judgement and expertise for the implementation is increasingly required. Concepts or principles-based standards rely on conceptual frameworks instead of "bright-lines" (Maines et al., 2003).

The theoretical underpinnings of this rule vs. principles based debate are embedded in the framework of Positive and Normative Accounting (Tinker et al., 1982). Under a dialectic Hegelian classification view (Limnatis, 2011) in academic literature rule-based only accounting is the thesis with the main contributor the FASB (Benston et al., 2006a; Schipper, 2003), for principles-based represented by the IASB (Carmona and Trombetta, 2008; Tweedie, 2007) as the antithesis and the synthesis is a combined view (Verheij et al., 1998; Wüstemann and Wüstemann, 2010).

So what are the reasons for such concerns about electronic reporting and with regard to the IFRS taxonomy? Do the answers to the conflict sit within the IFRS Standards, the technology or somewhere in between? How is this conflict considered in the academic literature on XBRL and taxonomies? How is the experience with mandatory electronic reporting in a specified taxonomy? Can the taxonomy from a normative perspective improve true and fair view? The purpose of this article is to provide answers to those research questions.

The structure of the article is that in a first step the foundation of XBRL and the development of taxonomies is explained and in general a taxonomy is defined. In a second step a literature review is performed which at the beginning summarizes the expressed views on the taxonomy development and principles-based standard setting. Do the academic authors share the view with the national standard setter that there is a conflict between principles-based standard setting and structured electronic reporting? The question in the academic literature is aligned to the assessment of what are the benefits and the challenges of structured electronic reporting. The combined benefits of structured electronic reporting are summarized based on the existing literature. Finally, those benefits are integrated into a model about Financial Accounting.

\section{Foundation of XBRL and the Development of Taxonomies}

Contrary to the worries of the national standard setters there are many sources in the academic literature, which emphasize the advantages (Roohani et al., 2010) and added value of structured electronic reporting using XBRL (Alles and Debreceny, 2012; Beerbaum, 2015; Piechocki, 2007). Structured electronic reporting: 
- facilitates user-driven data standardization and improves comparability;

- facilitates user-driven data standardization and improves comparability;

- provides computer-readable and complete disaggregation of disclosures;

- improves efficiency.

EXtensible Business Reporting Language is an international information format with the aim to exchange business information. Structured electronic reporting is without a taxonomy not possible. To develop a taxonomy is not something first invented by the upcoming electronic reporting. In fact, developing a taxonomy, which is a synonym for classification, has a long history and can be traced back even to the origin of human language (Beerbaum, 2015). The word "taxonomy" has its origin in the Greek verb "taxis", which means "classification", and the noun "nomia", which can be translated as "law". Combined and interpreted, it means "laws of classification" (Sharma et al., 2008).

Taxonomies are dictionaries for example for IFRS disclosure requirements, for which elements and relationships are defined based on the specific legislation and standards. XBRL has developed from a simple transmission log file for financial information into a comprehensive flexible set of technologies and represents the de-facto standard for the digital exchange of financial information (Piechocki and Felden, 2007). Through its flexible extensible structure it enables data modeling (and more importantly, multidimensional data modeling with XBRL Dimensions), financial data querying and setting of business rules (XBRL formulas) and also the visualization of business information (Inline XBRL and XBRL rendering). "Extensible" is one element of the XBRL, which describes the important advantage to add elements which are not founded in the base taxonomy, but are required e.g. due to local or industry specific requirements. Additionally, once the relationship between elements considering their order, addition or deletion needs to be changed this also requires to set up an extension, which are also named company specific elements (Debreceny et al., 2011).

The IFRS taxonomy enables companies to prepare financial statements to be fully compliant with the set standards and the requirements of regulators. It is comparable with an illustrative disclosure checklist, however with the difference that the investor will receive the result of the disclosure checklist, as XBRL taxonomy is part of the external submission.

It is surprising that XBRL technology has steadily evolved over time, however no corresponding evolution in the accounting standards setting process can be traced back. Most accounting standards still focus on document-oriented financial reporting for example, the major focus of IFRS and US GAAP is on the differentiation between core or face and notes of financial statements. While such an approach is based on tradition for accountants it is not the optimal approach for IT and data modeling experts or for data analysts. The latter has moved towards a 
more analytical view of business information which leads to multidimensional modeling with possibilities to slice, dice, and pivot or rotate multidimensional data. This means that one solution from a technological point of view might is the actual process of standard setting and the question how technology could improve efficiency. This discussion is taken up by the IASB, when in the due standard process also XBRL is planned to be integrated.

What could be actions from the Board, when setting IFRS Standards to facilitate structured electronic reporting? A principles-based standard setting faces several conflicts regarding the taxonomy development, since it is not geared by principles, but rather by single reporting requirements. Moreover, the IFRS taxonomy has faced international criticism that it is not sufficiently detailed. Therefore, it is not comparable and does not fulfil the requirements of a globally approved standard (Piechocki, 2007a). However, evidence suggests that the IFRS taxonomy will be integrated into a new European standard. The European Securities and Markets Authority (ESMA) started implementing the new EU transparency guidelines from 2013. The guidelines should help issuers facilitate submissions and make the submitted information easier accessible for investors and regulators, providing better analysis and comparability.

One of the rules of the new guideline requires issuers who are traded in a regulated EU market to prepare their annual reports in a common European electronic format the European Single Electronic Format (ESEF) as of 1 January 2020. Based on the feedback-statement made public by ESMA in December 2016 iXBRL will be required as the future technical standard. In many other European countries such as in the Netherlands XBRL will become the standard required for central bank data collection. As ESMA also decided in its feedback statement to pursue the IFRS taxonomy, this will increase the relevance of the IFRS taxonomy for many companies and enable a higher degree of comparability once implemented. Principles based accounting supporter argue that their approach is superior to a rule-based approach referring to the following arguments (Beerbaum, 2015):

- Provides guidance which enable infinite variations of requirements reflecting circumstances that arise in practice;

- Has the ability to steer rapid changes of the modern business environment;

- Avoids the development of a deterministic, "box-ticking" approach to decisionmaking and the use of legalistic loopholes to avoid compliance with guidance;

- Focuses on the spirit of the guidance and encourage responsibility and the exercise of professional judgement, which are key elements of professions.

Based on the ESMA consultation paper the experience with regard to mandatory electronic filing was summarized (Beerbaum and Piechocki, 2016): 
- XBRL is the dominant standard used for electronic reporting;

- Country compared different technologies to each other;

- Costs were underestimated by regulators.

To better understand why national standard setters challenge the development of a principles-based taxonomy further background about theoretical foundations of accounting and epistemological theories (theories about theorizing accounting) with the intention to trace back conflict to more fundamental thoughts and philosophical underpinnings are required.

\section{Fig. 1 Positive versus normative accounting theory}

\begin{tabular}{|l|l|l|}
\hline Content & $\begin{array}{l}\text { Seeks to develop a theory } \\
\text { that can explain observed } \\
\text { phenomena }\end{array}$ & $\begin{array}{l}\text { What should be the content } \\
\text { of financial statements? }\end{array}$ \\
\hline Objective & $\begin{array}{l}\text { Explain and predict } \\
\text { accounting practice }\end{array}$ & $\begin{array}{l}\text { Prescribe accounting } \\
\text { practice }\end{array}$ \\
\hline Represented by & $\begin{array}{l}\text { Zimmermann \& Watt } \\
(1978)\end{array}$ & Ijiri (1975) \\
\hline Research Method & Inductive $\rightarrow$ Rules-based & $\begin{array}{l}\text { Deductive } \rightarrow \text { Principles- } \\
\text { based }\end{array}$ \\
\hline
\end{tabular}

Source: Watts, R. L. and Zimmerman, J. L. (1990).

Positive accounting seeks to develop a theory that can explain observed phenomena. Normative accounting prescribes accounting practices. Principlesbased accounting can be allocated to normative accounting, while rule-based accounting is based on concepts about positive accounting. Normative challenges exist for principles-based taxonomy, as companies have to incorporate judgments into corporate reporting. Principles-based accounting framework seem to be in a constant practical conflict with rule-based accounting, which shows the example of guidelines. Guidelines are rules derived from principles and can help to overbridge judgement and subjective interpretations of principles. Accounting however also struggles from a theoretical point of view between normative and positive approaches, which is not unique as there are other disciples who have witnessed such a conflict (Tinker et al., 1982).

However, the recent conceptual conflict debate between IFRS principles-based and a prescriptive rule-based taxonomy does not follow those three groups, but the taxonomy limits the degrees of freedom and how regulations are implemented by IT and technology. Under an incremental approach (Previts, 2006), the IFRS taxonomy, as per substance prescriptive rule applied to IFRS becomes gradually more rule-based. 
Beerbaum, D. - Piechocki, M. - Weber, C.: Is there a Conflict between Principles-based Standard Setting and Structured Electronic Reporting with XBRL?

From a normative perspective the main objective of IFRS are the decision usefulness for investors, as managers should disclose financial statements applying a true and fair view (Scott, 2014).

There are also voices in the academic literature, which based on empirical evidence conclude that IFRS does not only follow a principles-based approach (Nobes, 2005). An argument is often cited that IFRS only appears more principlesoriented, as the IFRS are less matured than e.g. US GAAP (Parfet, 2000). With increasing duration of application of standards the demand for guidelines and clear and complete rules might increase.

Supporter of rule-based accounting argue that principles-based accounting requires a deep knowledge and expertise about the domain, and contrary to that compliance is easier since the requirements are prescriptive and leave little room for misunderstanding. Furthermore, rules-based approaches are easier to enforce. The key issue is striking an appropriate balance which encourages the spirit of the guidance to be complied with and does not undermine the exercise of judgement and the role of the profession.

\section{Literature Review Related to XBRL Taxonomy and Principles-based Accounting}

Going through the literature about XBRL and taxonomy with about 130 articles written between 1998 and 2016 and with the aim to identify the perceived conflict between a principles-based accounting standard and a taxonomy was in general difficult, as there are only limited sources, which cover exactly this specific topic. While early articles focus on the evolving internet financial reporting (Deller et al., 1999), XBRL starts to be mentioned as the language for the exchange of financial reporting by Charles Hoffmann (Hoffman and Strand, 2001). As national standard setters mention the taxonomy due process as a major issue to become more rulebased this first result is surprising, as the academic literature only in limited cases support the arguments from the national standard setters. As the IFRS taxonomy changes from a non-binding status to a mandatory in the EU, the due process needs to reflect this development and needs to be improved, however the US GAAP XBRL implementation has also shown that the quality of the taxonomy also increase with the application and usage of a taxonomy (Debreceny et al., 2011).

In the academic literature there are only limited examples, in which a conflict between structured electronic reporting and principles-based accounting is expressed, as XBRL is more seen as a positive enabler and an opportunity to increase efficiency. There are studies, which analyze the implementation of the IFRS taxonomy under local rule-based accounting regimes (Valentinetti and Rea, 
2012; Valentinetti and Rea, 2013). Valentinetti and Rea observe that the degree of misfit between the IFRS taxonomy and template-based standards not only varies with the sector but also with the size of the companies in the Italian market. Additionally, the type of disclosures also plays a role as main statement reveal very good fit while management report disclosures show high degree of misfit when comparing the IFRS taxonomy and the financial items.

Several sessions were held at the IASB in London to clarify this question and it was the consensus among the participants that technology is flexible and it is more the question how it is designed and used to support the principles-based accounting standard process.

Most of the authors within the XBRL academic literature focus on the process of the development of the taxonomy. The main arguments expressed are:

- IFRS taxonomy does not intend to create accounting standards, it just wants to represent the IFRS disclosure requirements as written in the IFRS Bound volume.

- Some authors point out to the issues that the IFRS taxonomy seems to be less detailed than a rule-based taxonomy such as US GAAP.

- One author provide business-related solutions how to extend the taxonomy, however the reason is not the perceived conflict but the aim to improve comparability and to standardize.

- According to Ramin et al. (Ramin and Reiman, 2013) the IASB XBRL Taxonomy and development by the IASB Foundation is one of the strongest support function for the standard setting process.

- Through the automatic translation features of XBRL financial reporting is pushed to the lowest level of implementation (Ramin and Reiman, 2013).

- Auditors are also involved in XBRL reviews although XBRL submission are not part of the audit opinion, as e.g. the AICPA issued "Performing Agreed upon Procedures Engagement" that address the completeness, mapping, consistency, or structure of XBRL-formatted information" (AICPA, 2016).

- XBRL is regarded as a defining factor in the principles vs. rule based debate, as tagged data facilitate to determine management judgements, which is one of the main critics from rule-based accounting supporters towards principles-based accounting (Cunningham, 2004).

- To become a useful tool for investors and other users of business information file XBRL require to be accurate and reliable, so that completeness and error free interactive files are a necessary precondition. 
Tab. 1 Literature review on taxonomy and principles-based standard setting

\begin{tabular}{|c|c|c|c|}
\hline Source & Summary & Conflict & Solution \\
\hline $\begin{array}{l}\text { Beerbaum } \\
\text { and } \\
\text { Piechocki } \\
(2016 a)\end{array}$ & $\begin{array}{l}\text { IFRS Taxonomy is not used very much in } \\
\text { practice. This is not understandable as } \\
\text { several advantages relate to the IFRS } \\
\text { taxonomy: principle-based accounting } \\
\text { standard does very often not define } \\
\text { specifically disclosure rules for each and } \\
\text { every topic, therefore to derive reporting } \\
\text { elements would be very difficult to } \\
\text { accomplish. A robust taxonomy } \\
\text { development and governance process } \\
\text { leading to the IFRS taxonomy simplifies the } \\
\text { task of interpretations and the actual } \\
\text { expression of reporting elements. }\end{array}$ & Yes & $\begin{array}{l}\text { Not specifically } \\
\text { mentioned. }\end{array}$ \\
\hline $\begin{array}{l}\text { Campanari } \\
(2012)\end{array}$ & $\begin{array}{l}\text { This work contributes to the discussion } \\
\text { regarding the comparability between } \\
\text { different IFRS financial statements and } \\
\text { analyzes potential paths to the construction } \\
\text { of more reliable, transparent and } \\
\text { comparable financial information. The } \\
\text { document results on academic } \\
\text { recommendations on how to enhance the } \\
\text { current IFRS taxonomy and potential } \\
\text { strategies for reaching a broad comparability } \\
\text { scenario in the near future. }\end{array}$ & Yes & $\begin{array}{l}\text { Extend Common } \\
\text { Practice approach: } \\
\text { - Extend sample of } \\
\text { - companies } \\
\text { Continue its } \\
\text { works with filers } \\
\text { - Should consider } \\
\text { to analyze } \\
\text { "outliers" for } \\
\text { sectors, countries } \\
\text { or companies }\end{array}$ \\
\hline
\end{tabular}

Building an XBRL taxonomy is not about

Piechocki and Felden (2007)

Piechocki (2007) creating a software product or knowledgebased system. It is creating a standardized taxonomy for a particular domain in order to enable standardized exchange of business reports.

Financial concepts which appear on business reports are more often based on regulatory documents issued by various authorities. The IFRS taxonomy describes financial reports prepared based on the IFRS Bound Volume. Elements defined in the taxonomy refer to the specific terms and concepts explained in the IFRS. For this reason, taxonomy is often provided with a reference linkbase that presents relationships between elements and external regulations or standards.
The authors develop a general taxonomy development process

No model, which can be in general also used for principles-based derived taxonomies.

Not specifically

No mentioned, as a conflict is not identified. 


\begin{tabular}{|c|c|c|c|}
\hline Source & Summary & Conflict & Solution \\
\hline $\begin{array}{l}\text { Richards, } \\
\text { Smith, and } \\
\text { Saeedi } \\
(2006)\end{array}$ & $\begin{array}{l}\text { XBRL does not intend to set new } \\
\text { accounting standards, but it intends to } \\
\text { standardize the XML-based tags that are } \\
\text { used in business reporting so that the } \\
\text { business reports prepared by organizations } \\
\text { can be more easily compared and collated } \\
\text { for regulatory and other purposes. }\end{array}$ & No & $\begin{array}{l}\text { The author describes } \\
\text { three different ways } \\
\text { of the creation of a } \\
\text { taxonomy: } \\
\text { - Collect annual } \\
\text { reports } \\
\text { (Common } \\
\text { Practice } \\
\text { elements) } \\
\text { - Use Big Four } \\
\text { sample } \\
\text { illustrative } \\
\text { financial report } \\
\text { samples } \\
\text { Derive based on } \\
\text { accounting } \\
\text { standards }\end{array}$ \\
\hline $\begin{array}{l}\text { Wagenhofer } \\
(2003)\end{array}$ & $\begin{array}{l}\text { First, the Internet changes the costs of } \\
\text { information processes and with it the } \\
\text { demand and supply of financial information } \\
\text { in capital markets. Second, Internet financial } \\
\text { reporting creates a demand for } \\
\text { standardization, which has been taken up } \\
\text { with the development of XBRL. It is argued } \\
\text { that while XBRL is designed to standardize } \\
\text { only the format of information, it will also } \\
\text { standardize contents and will have a kind of } \\
\text { reverse impact. }\end{array}$ & Yes & $\begin{array}{l}\text { The author } \\
\text { recommends a base } \\
\text { taxonomy, as } \\
\text { consumers of } \\
\text { financial reports } \\
\text { (capital markets) tend } \\
\text { to require } \\
\text { standardized } \\
\text { information to be } \\
\text { able to compare } \\
\text { better. XBRL itself } \\
\text { represents a solution. }\end{array}$ \\
\hline
\end{tabular}

Source: Beerbaum (2015); Beerbaum and Piechocki (2016b).

Whereas a rule-based taxonomy is only based on deduction the IFRS taxonomy is since 2012 inductively as well as deductively developed. Deductively, as the standard paragraphs and the examples for disclosures are derived de-jure from the bound volume. Inductively, as de-facto external reporting disclosures of companies are analyzed for common practice elements. This is a mechanism which is not required in a rule-based accounting framework just as US-GAAP, as industry specific requirements are explicit mentioned in the accounting requirements. A similar approach concerns German Gaap Accounting, which is code-based and defines for instance for financial institutions specific templatebased disclosures based on the German Bank Accounting (RechKredV).

The users identify several advantages with the XBRL reporting taxonomy:

- Reduce information asymmetries of the capital market (Yoon, Zo, \& Ciganek, 2011).

- Enables participants in the financial supply chain to improve the exchange of business reporting information (Piechocki, 2009). 
Beerbaum, D. - Piechocki, M. - Weber, C.: Is there a Conflict between Principles-based Standard Setting and Structured Electronic Reporting with XBRL?

- Provides users with a standardized format, enabling software applications to exchange information without data migration (Alles \& Piechocki, 2012).

- Enables the automatic processing of information with the help of software applications (Matherne \& Coffin, 2001).

- Reduction of costs, as XBRL supports automated processing of financial and non-financial information (Jones \& Willis, 2003).

- Facilitates the access to more granular data, including the reference to the domain concept, e.g. the accounting standard (Müller-Wickop, Schultz, \& Nüttgens, 2013).

- Consists of meta data including specifications about the reporting entity, which is required for the monthly management report and the interpretation of the information (Zabihollah, Charles, \& Norman, 2001).

- Multi-language and multi-translation support for all existing recognized international taxonomies (Kurt \& David, 2003).

- User has the flexibility to extend reporting elements due to company-specific reasons (Debreceny et al., 2011).

- Implements the core information needs of the user. XBRL does not require specification of text formatting, as the instance file is coded and not human readable (Branson, 2002). There exist viewers such as the SEC XBRL viewer, which enable conversion of the instance file and allow the report to be displayed in a standardized format.

These main advantages are summarized and transmitted into main user advantages, which are also based on a detailed literature study about XBRL.

Tab. 3 Main XBRL user advantages

\begin{tabular}{lllll}
\hline & $\begin{array}{l}\text { Reduce } \\
\text { Information } \\
\text { asymmetries } \\
\text { of the capital } \\
\text { market }\end{array}$ & $\begin{array}{l}\text { Increase } \\
\text { Efficiency: } \\
\text { multi-language } \\
\text { support and } \\
\text { extensions }\end{array}$ & $\begin{array}{l}\text { Reduce } \\
\text { cost of } \\
\text { publication }\end{array}$ & $\begin{array}{l}\text { Improve } \\
\text { compara- } \\
\text { bility } \\
\text { through } \\
\text { standardi- } \\
\text { zation }\end{array}$ \\
\hline Yoon et al. (2011) & $\mathrm{X}$ & $\mathrm{X}$ & $\mathrm{X}$ & $\mathrm{X}$ \\
Piechocki (2009) & $\mathrm{X}$ & $\mathrm{X}$ & $\mathrm{X}$ \\
Alles and Piechocki 2012 & & $\mathrm{X}$ & \\
Kurt and David 2003 & & $\mathrm{X}$ & \\
Debreceny et al. 2011 & & & & \\
\hline
\end{tabular}

Source: Müller-Wickop et al. (2013) and own source. 
One of the main advantages of XBRL is that it makes transparent if it is a mandatory or voluntary disclosure. Although many companies are very proactive in submitting additional communication on a voluntary basis, different reporting products are used for this: for instance, analysts' presentations. The voluntary disclosures are additionally reported to the mandatory disclosures related to the financial statements. What is often very difficult for the reader of the financial and non-financial communication is to identify mandatory or voluntary disclosures, as they are not explicitly flagged by the company.

The following paragraph will present a summary of the existing literature with regard to benefit assessment and advantages associated with the implementation of XBRL. The authors in the academic literature apply different indicators to make an assessment about the impact of XBRL adoption on the information quality and to evaluate whether XBRL implementation helped to increase the decision usefulness of the company's disclosures. The complementary element is that they are based on empirical data:

The first group of articles follow the concept of accruals, which often reflects the "degree of earnings management" of the company (Peng et al., 2011, p. 110). According to this article he finding is that after the implementation of XBRL, the level of accruals is lower, which reflects that XBRL adoption reduces investors' information search and analyzing costs. The second group considers information efficiency, change in stock return volatility and event return volatility. In the study with the largest sample ever collected, performed by Jong et al. (2012), several findings with regard to XBRL implementation could be identified. Post-XBRL introduction, increasing information efficiency, decreasing event return volatility and decreasing stock returns volatility for 428 firms $(1,53610-\mathrm{K}$ and 10-Q filings) could be observed. The third group focuses on the analyst and investor. According to Ly (2012), regression analysis reveals significant increases in analysts' coverage and the quality of their earnings forecasts after XBRL adoption.

Finally, Yoon et al. (2011) focus on more general indicators to assess the overall development of information asymmetries before and after the adoption of XBRL. The authors of the study apply various statistical methods consisting of t-tests as well as multiple regression analysis with the aim of analyzing the influence of XBRL adoption on information distribution related to the capital market. The main finding with regard to the study is that a material negative correlation between XBRL application and information asymmetry can be measured, which implies that XBRL improves the information distribution (Yoon et al., 2011). 
The following table provides a summary of additional academic literature about benefits of XBRL implementations. The studies can be allocated to the before mentioned "user advantages".

\section{Tab. 4 Literature review on benefits of XBRL}

\begin{tabular}{|c|c|c|c|c|}
\hline Focus & Main Findings & $\begin{array}{l}\text { Sample/ } \\
\text { Country }\end{array}$ & $\begin{array}{l}\text { Author of } \\
\text { Study }\end{array}$ & Method \\
\hline $\begin{array}{l}\text { Mandatory } \\
\text { XBRL Filings }\end{array}$ & $\begin{array}{l}\text { Level of accruals decreased post-XBRL, } \\
\text { information acquisition costs are lowered }\end{array}$ & $\begin{array}{l}\text { Shanghai Stock } \\
\text { Exchange and } \\
\text { Shenzhen } \\
\text { Stock } \\
\text { Exchange, } \\
\text { China }\end{array}$ & $\begin{array}{l}\text { (Wang \& } \\
\text { Seng, 2014) }\end{array}$ & $\begin{array}{l}\text { Statistical } \\
\text { analysis of } \\
\text { Financial } \\
\text { Statements } \\
\text { ex and } \\
\text { post-XBRL } \\
\text { implement } \\
\text { ation }\end{array}$ \\
\hline $\begin{array}{l}\text { Quantity and } \\
\text { Quality of } \\
\text { financial } \\
\text { information }\end{array}$ & $\begin{array}{l}\text { The mandatory XBRL adoption has led to } \\
\text { a significant improvement in both the } \\
\text { quantity and quality of information, as } \\
\text { measured by analyst following and } \\
\text { forecast accuracy. The impact of } \\
\text { mandatory XBRL adoption increases as } \\
\text { time passes. The implications of the } \\
\text { findings for policy and research are drawn. }\end{array}$ & $\begin{array}{l}1,430 \text { firm } \\
\text { listed in the } \\
\text { U.S from 2005- } \\
2010 \text {. }\end{array}$ & $\begin{array}{l}\text { (Liu, Wang, } \\
\& \text { Yao, 2014) }\end{array}$ & Empirical \\
\hline $\begin{array}{l}\text { Impact on } \\
\text { cost of capital }\end{array}$ & $\begin{array}{l}\text { This study examines the impact of initial } \\
\text { mandatory adoption of XBRL on } \\
\text { organizations' cost of capital and } \\
\text { transaction costs in PR China. As } \\
\text { transaction cost theory predicts, the } \\
\text { uncertainty related to the unproven } \\
\text { technology increases transaction costs and } \\
\text { the cost of capital during the early } \\
\text { adoption period. }\end{array}$ & $\begin{array}{l}\text { Listed } \\
\text { companies in } \\
\text { China }\end{array}$ & $\begin{array}{l}\text { (Liu, Luo, } \\
\text { Sia, O'farrell, } \\
\& \text { Teo, 2014) }\end{array}$ & Empirical \\
\hline
\end{tabular}

An increase in information efficiency, a decrease in event return volatility, and a reduction of change in stock returns

The effect of mandatory XBRL disclosure across various aspects of the financial information environment. volatility for) post-XBRL disclosure. In addition, this study shows that XBRL mitigates information risk in the market, especially when there is increased uncertainty in the information environment. Our results are robust to various alternative specifications and research modifications, such as a matchedpair control (326 XBRL versus 326 nonXBRL firms), current stock market condition, potential earnings releases, and corporate governance.

$\begin{array}{lll}\text { 428 U.S. listed } & & \text { Financial } \\ \text { firms }(1,536 & \text { (Kim, Lim, \& } & \text { Statements } \\ \text { 10-K and 10-Q } & \text { No, 2012) } & \text { ex and } \\ \text { filings } & & \text { post-XBRL } \\ & & \text { implement } \\ & & \text { ation }\end{array}$

Statistical analysis of Financial ex and ation 
European Financial and Accounting Journal, 2017, vol.12, no. 3, pp. 33-52.

\begin{tabular}{|c|c|c|c|c|}
\hline Focus & Main Findings & $\begin{array}{l}\text { Sample/ } \\
\text { Country }\end{array}$ & $\begin{array}{l}\text { Author of } \\
\text { Study }\end{array}$ & Method \\
\hline $\begin{array}{l}\text { Quantitative } \\
\text { financial } \\
\text { information }\end{array}$ & $\begin{array}{l}\text { Firms increase their quantitative footnote } \\
\text { disclosures upon adoption of XBRL } \\
\text { detailed tagging requirements. Non- } \\
\text { adopting firms are used as a benchmark to } \\
\text { control for market wide changes in } \\
\text { disclosure and the results of increased } \\
\text { disclosure hold in this difference-in- } \\
\text { difference design. }\end{array}$ & $\begin{array}{l}323 \text { US listed } \\
\text { firms, which } \\
\text { provided } \\
\text { detailed } \\
\text { tagging. }\end{array}$ & $\begin{array}{l}\text { (Blankespoor, } \\
\text { 2012) }\end{array}$ & $\begin{array}{l}\text { Statistical } \\
\text { analysis of } \\
\text { Financial } \\
\text { Statements } \\
\text { ex and } \\
\text { post-XBRL } \\
\text { implement } \\
\text { ation }\end{array}$ \\
\hline $\begin{array}{l}\text { Voluntary } \\
\text { XBRL Filings }\end{array}$ & $\begin{array}{l}\text { Voluntary XBRL filings have incremental } \\
\text { information content. } \\
1.2 \% \text { to } 8.0 \% \text { of the general information } \\
\text { content in earnings disclosures is related to } \\
\text { XBRL filings }\end{array}$ & $\begin{array}{l}\text { Voluntary } \\
\text { Filing Program } \\
\text { SEC; Sample: } \\
342 \text { Filings } \\
\text { from } 2005 \text { to } \\
\text { June } 30,2008\end{array}$ & $\begin{array}{l}\text { (Efendi, Park, } \\
\& \\
\text { Subramaniam } \\
\text {, 2010) }\end{array}$ & $\begin{array}{l}\text { Non- } \\
\text { directional } \\
\text { test to } \\
\text { detect } \\
\text { market } \\
\text { reactions } \\
\text { based on } \\
\text { Patell } \\
(1976)\end{array}$ \\
\hline $\begin{array}{l}\text { Corporate } \\
\text { Governance }\end{array}$ & $\begin{array}{l}\text { Voluntary filers with the SEC using the } \\
\text { XBRL format are associated with superior } \\
\text { CG and operating performance relative to } \\
\text { their peers }\end{array}$ & $\begin{array}{l}\text { Authors use a } \\
\text { CG index to } \\
\text { rank } \\
\text { companies. }\end{array}$ & $\begin{array}{l}\text { Bhattacharya } \\
\text { (2008) }\end{array}$ & Empirical \\
\hline
\end{tabular}

Source: Beerbaum (2015); Beerbaum and Piechocki (2016b).

To be in a position to understand the benefit from XBRL the empirical results of the academic literature are integrated into a model about Financial accounting from Scott (Scott, 2014). This shows, that from XBRL implementation consumers and provider of financial information can benefit, however there are also areas within the model, for which XBRL is not suitable to enable an improvement. 
Fig. 2 Financial Accounting Model and XBRL

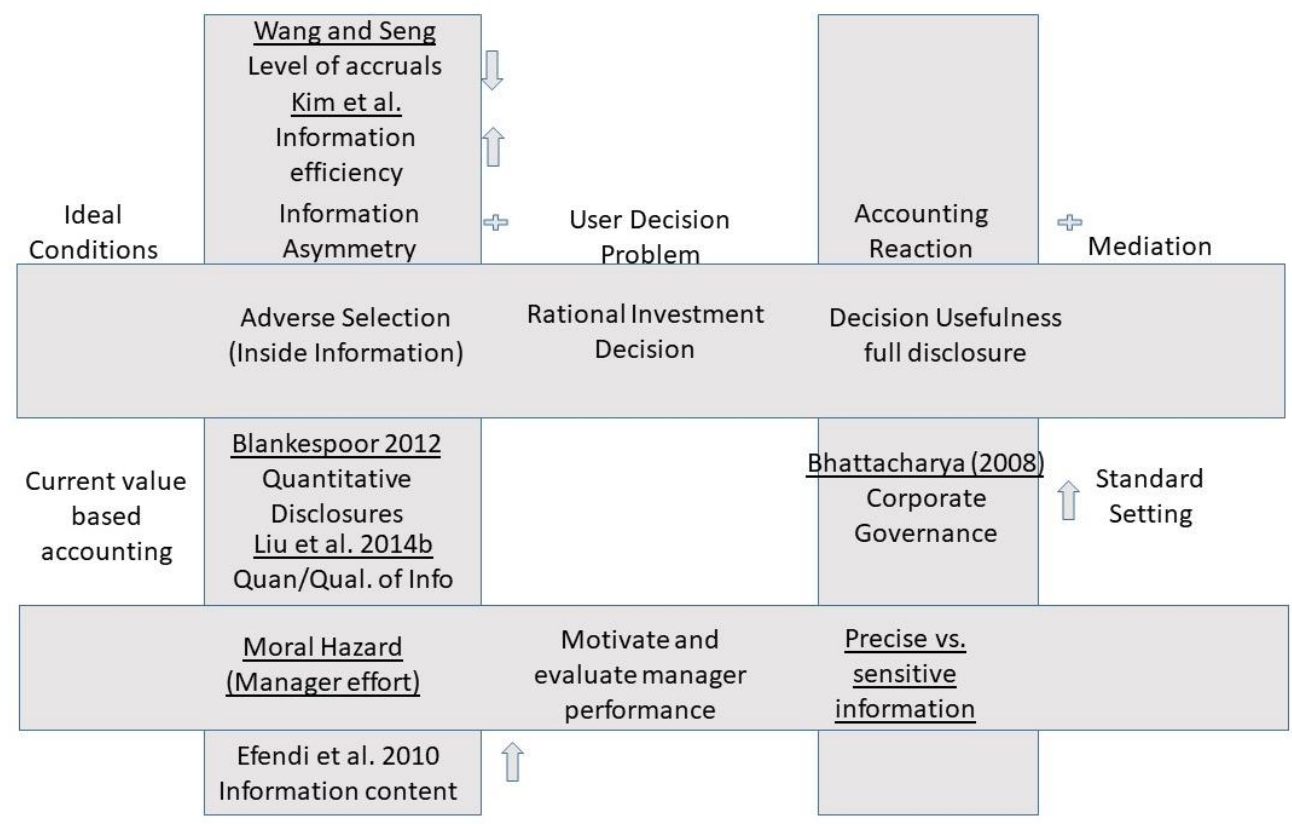

Source: Scott (2014) and own development.

\section{Conclusion}

Although there is a conceptual conflict between a principles-based accounting standard and the development of a taxonomy compared to a template based rulebased accounting framework, this appears in the case of the IFRS taxonomy as only a minor one. IFRS Taxonomy development faced this conflict for many years and is well aware of that. There is a deficiency in common practice elements, as they provide only partly detailed report elements, since they are only included in the IFRS taxonomy when they are reported by the majority of firms. On the other hand, this means that a minority of the common reporting elements are not considered in the IFRS taxonomy.

Considering the literature review, most of the authors focus on the process of the development of the taxonomy and intend to extend the number of tags. On the one hand, there are only limited examples, in which a conflict is expressed. On the other hand, there is indeed a conflict between principles-based accounting and the taxonomy, as IFRS does not contain many specific disclosure requirements and therefore a high level of degrees of freedom exist, which becomes restricted by the taxonomy. 
However, the advantages of a standardized unified taxonomy are obvious: improvement of comparability, reduced transaction costs for analysts when financial reporting information are analytically processed. As a consequence more precise analyst forecast and reduced information asymmetries, for which the referenced studies provide an indication of confirmation.

An important question to answer will be how a provided taxonomy will have to be applied mandatorily and which degrees of freedom or options finally remain. This is particularly relevant for the application of a materiality concept and in this context the question if information can be omitted or aggregated. A mandatorily application would be against the principles-based accounting standard. Applying company specific elements or individual extensions would not violate against principles-based accounting, whereas the comparability would be limited.

\section{References}

AICPA, 2016. SOP 13-2 Performing Agreed-Upon Procedures Engagements XBRL-Formatted Information: Wiley. DOI: 10.1002/9781119233510.ch51.

Alles, M., Debreceny, R., 2012. The evolution and future of XBRL research. International Journal of Accounting Information Systems 2, 83-90. DOI: 10.1016/j.accinf.2012.03.006.

Alles, M., Piechocki, M., 2012. Will XBRL improve corporate governance? A framework for enhancing governance decision making using interactive data. International Journal of Accounting Information Systems 2, 91-108. DOI: $10.1016 /$ j.accinf.2010.09.008.

Beerbaum, D., 2015. Towards an XBRL-enabled corporate governance reporting taxonomy. An empirical study of NYSE-Listed Financial Institutions. SSRN Electronic Journal. DOI: 10.2139/ssrn.2857976.

Beerbaum, D., Piechocki, M., 2016. On the Path to an European Single Electronic Format-ESMA Consultation for the IFRS Taxonomy of Structured Electronic Reporting. SSRN Electronic Journal. DOI: 10.2139/ssrn.2866747.

Benston, G. J., Bromwich, M., Wagenhofer, A., 2006. Principles- versus rulesbased accounting standards: The FASB's standard setting strategy. Abacus 2, 165-188. DOI: 10.1111/j.1467-6281.2006.00196.x.

Bonsón, E., Cortijo, V., Escobar, T., 2009. Towards the global adoption of XBRL using International Financial Reporting Standards (IFRS). International Journal of Accounting Information Systems 1, 46-60. DOI: 10.1016/j.accinf.2008.10.002. 
Beerbaum, D. - Piechocki, M. - Weber, C.: Is there a Conflict between Principles-based Standard Setting and Structured Electronic Reporting with XBRL?

Bradbury, M. E., Schröder, L. B., 2012. The content of accounting standards: Principles versus rules. The British Accounting Review 1, 1-10. DOI: 10.1016/j.bar.2011.12.003.

Branson, M., 2002. Using XBRL for data reporting. Statistical Journal of the United Nations Economic Commission for Europe 19, 201-204. DOI: 10.3886/icpsr02572.v1.

Carmona, S., Trombetta, M., 2008. On the global acceptance of IAS/IFRS accounting standards: The logic and implications of the principles-based system. Journal of Accounting and Public Policy 6, 455-461. DOI: 10.1016/j.jaccpubpol.2008.09.003.

Cohen, E. E., 2004. CAP Forum on E-Business: Compromise or Customize: XBRL's Paradoxical Power. Accounting Perspectives 3, 187-206. DOI: 10.1506/yahn-cae8-5cwq-h4te.

Cunningham, C., 2004. Cheaper, better, faster: XBRL takes center stage in financial reporting. Financial Executive 20, 6-7. DOI: doi.org/10.1007/978-38350-9633-2_3.

Debreceny, R., Felden, C., Ochocki, B., Piechocki, M., Piechocki, M., 2009. XBRL Taxonomy Engineering, XBRL for Interactive Data, 113-127. DOI: 10.1007/978-3-642-01437-6_6.

Debreceny, R. S., Farewell, S. M., Piechocki, M., Felden, C., Gräning, A., d'Eri, A., 2011. Flex or Break? Extensions in XBRL Disclosures to the SEC. Accounting Horizons 4, 631-657. DOI: 10.2308/acch-50068.

Deller, D., Stubenrath, M., Weber, C., 1999. A survey on the use of the Internet for investor relations in the USA, the UK and Germany. European Accounting Review 2, 351-364. DOI: 10.1080/096381899336087.

Healy, P. M., Palepu, K. G., 2003. The fall of Enron. The Journal of Economic Perspectives 2, 3-26. DOI: 10.1257/089533003765888403.

Hoffman, C., Strand, C., 2001. XBRL Essentials: American Institute of Certified Public Accountants. DOI: 10.5860/choice.41sup-0391.

IASB, 2016. Comments on proposed Amendments to the IFRS Taxonomy due process 2015. DOI: 10.1002/9781119200543.ch2.

Jones, A., Willis, M., 2003. The challenge of XBRL: business reporting for the investor. Balance Sheet 3, 29-37. DOI: 10.1108/09657960310491172.

Kurt, P. R., David, A. P., 2003. Building an XBRL IFRS taxonomy. The CPA Journal 73, 50. DOI 10.1002/9781119208099. 
Limnatis, N. G., 2011. The Dimensions of Hegel's Dialectic. Bloomsbury Publishing, London. DOI: 10.5040/9781472548306.ch-026.

Maines, L. A., Bartov, E., Fairfield, P., Hirst, D. E., Iannaconi, T. E., Mallett, R., Schrand, C. M., Skinner, D. J., Vincent, L., 2003. Evaluating concepts-based vs. rules-based approaches to standard setting. Accounting Horizons 1, 73-89. DOI: 10.2308/acch.2003.17.1.73.

Matherne, L., Coffin, Z., 2001. XBRL: A Technology Standard to Reduce Time, Cut Costs, an Enable Better Analysis for Tax Preparers. Tax Executive 53, 67-68. DOI: 10.15760/etd.1171.

Müller-Wickop, N., Schultz, M., Nüttgens, M., 2013. XBRL: Impacts, Issues and Future Research Directions, Lecture Notes in Business Information Processing, 112-130. DOI: 10.1007/978-3-642-36219-4_7.

Nelson, M. W., 2003. Behavioral evidence on the effects of principles-and rulesbased standards. Accounting Horizons 1, 91-104. DOI: 10.2308/acch.2003.17.1.91.

Nobes, C. W., 2005. Rules-based standards and the lack of principles in accounting. Accounting Horizons 1, 25-34. DOI: 10.2308/acch.2005.19.1.25.

Parfet, W. U., 2000. Accounting subjectivity and earnings management: A preparer perspective. Accounting Horizons 4, 481-488. DOI: $10.2308 /$ acch.2000.14.4.481.

Piechocki, M., 2007a. Conception of XBRL Use in the Financial Reporting Supply Chain. Tagungsband zum Doctoral Consortium der WI 2007 133, 43-58.

Piechocki, M., 2007b. XBRL financial reporting supply chain architecture: Freiberg <Sachsen> : TU Bergakademie Freiberg.

Piechocki, M., Felden, C., 2007. XBRL Taxonomy Engineering. Definition of XBRL Taxonomy Development Process Model, ECIS, 889-900. DOI: 10.1007/978-3-642-01437-6_6.

Piechocki, M., Felden, C., Gräning, A., Debreceny, R., 2009. Design and standardisation of XBRL solutions for governance and transparency. International Journal of Disclosure and Governance 3, 224-240. DOI: 10.1057/jdg.2009.9.

Previts, G., 2006. Research in Accounting Regulation. Elsevier Science, Amsterdam. DOI: doi.org/10.1016/s1052-0457(02)16018-8.

Ramin, K., Reiman, C., 2013. IFRS and XBRL: How to improve Business Reporting through Technology and Object Tracking. Wiley corporate F \& A, Padstow. DOI 10.1002/9781119208099. 
Beerbaum, D. - Piechocki, M. - Weber, C.: Is there a Conflict between Principles-based Standard Setting and Structured Electronic Reporting with XBRL?

Roohani, S., Xianming, Z., Capozzoli, E. A., Lamberton, B., 2010. Analysis of XBRL literature: A decade of progress and puzzle. The International journal of digital accounting research 10. DOI: 10.4192/1577-8517-v10_6.

Schipper, K., 2003. Principles-based accounting standards. Accounting horizons 1, 61-72. DOI: 10.2308/acch.2003.17.1.61.

Scott, W. R., 2014. Financial Accounting Theory. Pearson Education, London.

Sharma, R., Foo, S., Morales-Arroyo, M., 2008. Developing Corporate Taxonomies for Knowledge Auditability-A Framework for Good Practices. Journal of Knowledge Organization 35. DOI: 10.1142/9789812701527_0011.

Tinker, A. M., Merino, B. D., Neimark, M. D., 1982. The normative origins of positive theories: ideology and accounting thought. Accounting, Organizations and Society 2, 167-200. DOI: 10.1016/0361-3682(82)90019-8.

Tweedie, D., 2007. Can global standards be principle based? Journal of Applied Research in Accounting and Finance (JARAF) 2, 3-8.DOI: 10.1111/j.17455871.2007.00463.

Valentinetti, D., Rea, M. A., 2012. IFRS Taxonomy and financial reporting practices: The case of Italian listed companies. International Journal of Accounting Information Systems 2, 163-180. DOI: 10.1016/j.accinf.2011.09.001.

Valentinetti, D., Rea, M. A., 2013. XBRL for Financial Reporting: Evidence on Italian GAAP versus IFRS. Accounting Perspectives 3, 237-259. DOI: $10.1111 / 1911-3838.12008$.

Verheij, B., Hage, J. C., Van Den Herik, H. J., 1998. An integrated view on rules and principles. Artificial Intelligence and Law 1, 3-26. DOI: 10.1023/a:1008247812801.

Wüstemann, J., Wüstemann, S., 2010. Why Consistency of Accounting Standards Matters: A Contribution to the Rules-Versus-Principles Debate in Financial Reporting. Abacus 1, 1-27. DOI: 10.1111/j.1467-6281.2010.00304.x. 